\title{
Derleme
}

Mersin Univ Saglık Bilim Derg 2021;14(2):342

doi: 10.26559/mersinsbd.842650

\section{Besinlerle alınan endokrin bozucuların pubertal gelişim üzerine etkisi}

\author{
Gül Eda Kılınç'1, (DIlev Keser ${ }^{1}$ \\ ${ }^{1}$ Ankara Üniversitesi Sağllk Bilimleri Fakültesi Beslenme ve Diyetetik Bölümü
}

Öz

Puberte, üreme işlevine ulaşmak için adolesanın bedeninde meydana gelen bir dizi gelişimsel değișiklerdir. Pubertal gelișim nöroendokrin sistem tarafından kontrol edilmektedir ve pubertal zaman üzerinde birçok faktör etkili olmaktadır. Bu faktörler arasında nöroendokrin sistemi önemli düzeyde etkileyen endokrin bozucular yer almaktadır. Endokrin bozucular; endokrin sistem fonksiyonlarını etkileyerek organizmanın sağlığı üzerinde olumsuz etkiler meydana getirmektedirler. $\mathrm{Bu}$ etkilerini ise hormonların sentez, taşınma, metabolizma, bağlanma reaksiyonları, aktiviteleri, vücuttan atılımları ve hatta hedef hücredeki etkilerini değiştirebilme özellikleri yoluyla gerçekleştirmektedirler. Endokrin çevre bozucuların insan sağlığı üzerine olası etkileri giderek tartışmaların odağı haline gelmektedir. Endokrin çevre bozan kimyasallar; plastiklerde, deterjanlarda, böcek ilaçlarında ve endüstriyel kimyasallarda bulunmaktadırlar. Endokrin bozucuların bir kısmı lipofilik yapıda olup yağ dokusunda birikir, bir kısmı ise özellikle gelişimin kritik bir periyodu sırasında önemli rollere sahiptir. Pubertal gelişim üzerinde özellikle sentetik ve çevresel endokrin bozucular etkili olmakta ve bunların vücuda alınmasında beslenmenin oldukça önemli bir etkisi bulunmaktadır. Besinler özellikle üretim, depolama ve işleme yöntemleri sırasında endokrin bozucular ile kontamine olmaktadır. Endokrin bozucuların vücut üzerine etkileri, bireylerin lipid profili, oksidatif stres düzeyi, antioksidan kapasiteleri ve beslenme durumu gibi birçok faktöre bağlı olarak değişiklik gösterebilmektedir. Bunun yanında çok sayıda hayvan ve insan çalışması, besinler yoluyla alınan endokrin bozucuların pubertal gelișim üzerine olumsuz etkilerini ortaya koymaktadır. Ancak çalışma sonuçları, endokrin bozuculara maruziyet zamanına (prenatal, perinatal ve pubertal) ve endokrin bozucu kimyasal bileșenlerin antagonist etkilerine yönelik konularda yetersiz kalmaktadır. Bu derlemede özellikle besinler yoluyla maruz kalınan endokrin bozucuların pubertal gelişim üzerine etkisinin literatüre dayalı olarak tartışılması amaçlanmıştır.

Anahtar kelimler: Besin, endokrin bozucular, puberte

Yazının geliş tarihi: 17.12.2020

Yazının kabul tarihi: 04.03.2021

Sorumlu Yazar: Gül Eda Kılınç, Ankara Üniversitesi, Sağlık Bilimleri Fakültesi, Beslenme ve Diyetetik Bölümü, Keçiören/Ankara, Tel: 3122126040, E-posta: dyt.edaa@gmail.com 


\title{
The effect of endocrine disruptors in foods on pubertal development
}

\begin{abstract}
Puberty is a series of developmental changes that occur in body of adolescent to achieve reproductive function. Pubertal development is controlled by the neuroendocrine system and many factors affect pubertal time. Among these factors are endocrine disruptors that significantly affect the neuroendocrine system. Endocrine disruptors affect functions of endocrine system by creating negative effects on health of the organism. These effects are realized through the synthesis, transport, metabolism, binding reactions, activities, excretion of the hormones and even the ability to change their effects in the target cell. Possible effects of endocrine disruptors on human health are becoming focus of discussion. Endocrine disrupting chemicals are found in plastics, detergents, pesticides and industrial chemicals. Some endocrine disruptors are lipophilic and accumulate in adipose tissue, and some have important roles, especially during a critical period of development. Synthetic and environmental endocrine disruptors are especially effective on pubertal development and nutrition has a significant effect on their absorption into body. Foods are contaminated with endocrine disruptors, especially during production, storage and processing methods. Effects of endocrine disruptors on the body can vary depending on many factors such as individuals' lipid profile, oxidative stress level, antioxidant capacities and nutritional status. Numerous animal and human studies reveal negative effects of endocrine disruptors on pubertal development. However, results of the study are insufficient regarding time of exposure to endocrine disruptors (prenatal, perinatal and pubertal) and antagonist effects of endocrine disrupting chemical components. Therefore, main objective of this review is to discuss effects of endocrine disruptors exposed on foods through pubertal development based on the literature.
\end{abstract}

Keywords: Endocrine disruptors, food, puberty

\section{Giriş}

Puberte, bir çocuğun bedeninde yetişkin üreme işlevine ulaşmak için meydana gelen bir dizi gelişimsel değiş̧ikler olarak tanımlanmaktadır. Pubertal olgunluk, hipotalamus-hipofiz-gonad (HHG) ekseninin aktivasyonu sonucunda cinsiyet streoidlerinin üretimi ve ikincil cinsiyet karakterlerinin oluşumunu sağlayan hipotalamustan salınan gonadotropin salgılatıcı hormon (GnRH) artışı ile başlamaktadır. ${ }^{1}$ Pubertenin başlaması ile birlikte kızlarda meme tomurcuklanması, erkeklerde ise testis büyüklüklerinde artış meydana gelmektedir. $\mathrm{Bu}$ değişimler kızlarda ortalama 10-12, erkeklerde ise ortalama 12-14 yașında bașlamaktadır. Dünya Sağlık Örgütü (WHO), 10-19 yaş aralığını puberte dönemi olarak tanımlamaktadır. ${ }^{2}$
Kızlarda sekiz, erkeklerde ise dokuz yaşından önce HHG ekseninin aktivasyonuna bağlı olarak ikincil cinsiyet özelliklerinin gelişmesi santral erken puberte (SEP) olarak tanımlanmaktadır. Santral erken puberte sıklığının 1/5,000-10,000 arasında değiștiği ifade edilmektedir. Erken pubertal gelişim yaşayan çocuklara; ikincil cinsiyet karakterlerinde gelişim geriliği, nihai boyda kısalık, kemik yaşında ilerleme, vücut görünümünde orantısızlık, zayıf beden imajı algısı, madde bağımlılı̆̆ı, depresyon ve yeme bozuklukları gibi birçok sorun eşlik etmektedir. ${ }^{3}$ Puberte zamanında gecikme olduğunda ise yeme bozuklukları, depresyon ve düşük kemik mineralizasyonu gibi psikososyal patoloji riski artmaktadır. Ayrıca erken menarş ile birlikte üreme sistemi kanserleri riski artabilmektedir. Diğer yandan, prematüre adrenarş ile ilerleyen yıllarda obezite, diyabet ve kardiyovasküler hastalık gelişme riski arasında bir ilişki 
olduğu öne sürülmektedir. $\mathrm{Bu}$ nedenle pubertenin zamanında ve sağlıklı bir şekilde gelişmesi, topluma fiziksel, bedensel ve cinsel gelişimlerin yanı sıra, duygusal, ahlâkî, sosyal ve psikolojik açıdan sağlıklı bireylerin kazandırılması açısından önemlidir. Puberteye başlama yaşı, yaşamın ileriki yılları için oldukça önemli olup erken puberteyi tetikleyen faktörler henüz tam olarak bilinmemektedir. Ancak, puberteye başlama zamanının genetik ve etnik özelliklerin yanında beslenme durumu, nörotransmitterler, hormonlar ve çevresel faktörler arasındaki ilişkiden etkilendiği düşünülmektedir. ${ }^{4}$

Çevresel faktörlerden endüstriyel kirlenme günümüzde önemli oranda artmaktadır. Doğal ve sentetik olan bu çevresel kirlenmelerden bazıları endokrin sistem üzerinde oldukça etkili olmaktadır. Endokrin sistem üzerinde negatif etki gösteren kimyasallar, endokrin bozucular olarak tanımlanmaktadır. Endokrin bozucular, hormon reseptörlerini bağlayarak, doğrudan hücre içi sinyal yolaklarını etkileyerek, merkezi sinir sistemi ile nöroendokrin sistem üzerine etkileri yoluyla hormon sentezini baskllayarak veya ilişkili organlar üzerinde toksik etki yaratarak puberte zamanını değiștirebilmektedir. ${ }^{5}$ Derleme olarak hazırlanan bu makalede, özellikle besinler yoluyla maruz kalınan endokrin bozucuların puberte üzerine etkisinin literatüre dayalı olarak tartışılması amaçlanmıştır.

\section{Endokrin Bozucular}

Endokrin bozucular temel olarak doğal, yapay ve çevresel olmak üzere üç ana başlık altında incelenmektedir.

Doğal endokrin bozucular'dan en bilineni fitoöstrojenlerdir. Fitoöstrojenler, östrojenle aynı kimyasal yapıya sahip olup östrojen reseptörü üzerinde uyarıcı ve engelleyici işlevlere sahiptir. İzoflovanlar, daidzein ve genistein soya kaynaklı fitoöstrojenler olup infant formülalarında oldukça yüksek konsantrasyonda bulunmaktadırlar Soya bazlı formülaların yüksek miktarda alımının çocukluk çağı gelişiminde potansiyel olumsuz etkileri olduğu bildirilmektedir. 6 İngiltere'de 2922 kız çocuğunun dahil edildiği bir çalışmada, 4 aydan önce soya bazlı formüla ile beslenen infant kızlarda, dört aydan sonra soya bazlı formüla ile beslenen kızlara kıyasla menarş yaşının daha erken olduğu belirlenmiştir. ${ }^{7}$ Başka bir çalışmada, plazma düzeylerinde yüksek izoflovan konsantrasyonlarının kızlarda erken meme gelişimi ve erken pubertal zaman ile ilișkili olduğu belirtilmiştir. ${ }^{8}$ Benzer şekilde, adölesan dönemdeki 248 erkek çocuğu ile yapılan bir çalışmada orta ve yüksek fitoöstrojen alımı ile erken pubertal gelişim arasında pozitif yönde bir ilişki olduğunu saptamıştır. ${ }^{9}$

\section{Sentetik endokrin bozucular} endüstride, tarımda ve evde kullanılan değişik ürünlerin içerisinde bulunurlar. $\mathrm{Bu}$ grupta doğum kontrol ilaçları, sentetik hormonlar ve bazı hayvansal gida katkı maddeleri yer almaktadır. Çevremizde birçok kimyasal toksin bulunmakla birlikte bunlardan bazıları endokrin bozukluklara neden olmaktadır. Bunların arasında organik bileșene sahip olanlar, besin zinciri yoluyla insan vücuduna alınmaktadır. Özellikle, hayvancılıkta hastalıkların önlenmesi ve verimin artırılması amaciyla bazı antibiyotikler ve anabolik hormonlar kullanılmaktadır. ${ }^{10}$

Çevresel endokrin bozucular ise genel olarak endüstri alanında kullanılmak üzere geliștirilmiş kimyasallar ve farklı çevresel kirleticilerdir. Bu grupta; biyosidler, insektisitler, herbisitler, nematositler, fungusitler, endüstriyel kimyasallar (bisfenol A, polivinil karbon) ve ağır metaller yer almaktadır. Pestisidler; dikloro difenil trikloroethan (DDT), endosülfan, dieldrin, metoksiklor, kepon, dikofol, toksofen gibi böcek ilaçlarını; alaklor, atrazin, nitrofen gibi bitki ilaçlarını; benomil, mankozeb ve tribütiltin gibi mantar ilaçlarını; aldikarb, bibromokloropropan gibi parazit ilaçlarını içermektedir. Pestisitler, bitkisel ve hayvansal besinlerle vücuda alınarak insan dokularında zararlı etkiler yaratmaktadır. $\mathrm{Bu}$ zararlı etkilerden biri de erken puberte gelişimidir. ${ }^{11}$

Endokrin bozucuların erken puberte üzerine potansiyel etkileri ilk defa 1990'lı yılların başında saptanmış, daha sonra bu konuya ilgi giderek artmıştır. ${ }^{12}$ Erken 
puberteyi tetikleyen mekanizmalar hala net olarak anlaşılamamıştır. Ancak temel olarak genetik, çevresel ve hormonal etkileşimlerin sonucu meydana geldiği düşünülmektedir. Endokrin bozucular, su, hava, besinler ve çeşitli çevresel faktörler yolu ile insan vücuduna alınabilmekte ve etkilerini, uzun süre maruz kalınması sonucunda gösterebilmektedir. Ayrıca endokrin bozucular, anneden plasenta aracilığ ile fetüse, anne sütüyle bebeğe geçebilmektedir. Hormon benzeri özelliklerinden dolayl, endokrin sistem üzerine etki edebilmekte, agonist veya anti-agonist etki gösterebilmektedir. ${ }^{13}$

Endokrin bozucular, östrojenik, androjenik, anti-androjenik aktiviteleriyle veya doğrudan GnRH üzerinden puberte zamanını değiștirmektedir. Bu kimyasallar, östrojenik etkilerini östrojen reseptörlerini bağlayarak, aromataz aktivitelerini, östrojen duyarlılığını artırarak ya da endojen östrojen üretimini artırarak gerçekleştirmektedir. Tüm bu etkiler, erken puberteye neden olabilmektedir. Endokrin bozucular aromataz enzim aktivitesini ve steroidojenik enzim üretimini engelleyerek antiöstrojenik ve androjenik etkileri tetiklemektedir. Antiandrojenik etkilerini, testikular steroidojenezis ve androjen reseptör baskılanması yoluyla göstermektedirler. $\mathrm{Bu}$ nedenle endokrin bozucuların etki mekanizmalarına bağlı olarak erken veya gecikmiş puberte veya cinsiyet farklılık bozuklukları meydana gelebilmektedir.12 Ayrıca, dişi puberte zamanının histon modifikasyonları, DNA metilasyonu ve kodlamayan RNA gibi epigenetik mekanizmalar tarafından da kontrol edildiği öne sürülmektedir. ${ }^{14}$ Endokrin bozucular gibi çevresel faktörler birçok doku işlevinin düzenlenmesinde etkili olmaktadır. Endokrin bozucuların, epigenetik yolaklarla hipotalamik nöronlar üzerinde etkili olduğu düşünülmekte ancak mekanizması net bir şekilde açıklanamamaktadır.

\section{Besinler ile Alınan Endokrin Bozucular}

Endokrin bozucuların vücuda alınmasında beslenmenin oldukça önemli bir etkisi vardır. Besinler özellikle üretim, depolama ve işleme yöntemleri sırasında endokrin bozucular ile kontamine olmaktadır. Endokrin bozucuların vücut üzerine etkileri, bireylerin lipid profili, oksidatif stres düzeyi, antioksidan kapasiteleri ve beslenme durumu gibi birçok faktöre bağlı olarak değişiklik gösterebilmektedir. ${ }^{12}$

\section{Ağır metaller}

Besinler yoluyla en fazla maruz kalınan endokrin bozucular; çeşitli yollarla çevreye, çevreden tahıllara, otlara, bunlarla beslenen hayvanlardan süt ve etlerine, kirlenmiş sulardan avlanılan canlılara veya yiyeceklerin üretimi sırasında kullanılan araç ve gereçlerden bulaşan ağır metallerdir. Günümüzde ağır metallere maruz kalma riski endüstrileșmenin de etkisiyle gün geçtikçe artmaktadır. Örneğin Türkiye'de bir sanayi kentinde, endüstriyel ve endüstriyel olmayan bölgelerde havadaki partikül kütlesini (PM 10) ve gebeliği boyunca takip edilen annelerin kolostrumu ve yeni doğanın mekonyumunda ağır metal varlığını değerlendirmek amacıyla yapılan bir çalışmada, her iki bölgede ortalama PM10 düzeyinin Dünya Sağlık Örgütü limit değerlerinden daha yüksek olduğu saptanmıştır. Ayrıca, kolostrum ve mekonyumdaki $\mathrm{Al}, \mathrm{As}, \mathrm{Cd}, \mathrm{Cu}, \mathrm{Fe}, \mathrm{Hg}$, $\mathrm{Pb}$ ve $\mathrm{Zn}$ gibi ağır metallerin ortalama konsantrasyonlarının, sanayi bölgesindeki örneklerde, endüstriyel olmayan bölgeye kıyasla daha yüksek olduğu belirlenmiştir. ${ }^{15}$

\section{a. Kurşun}

Besinlere kontamine olabilen başlıca ağır metallerden biri kurşundur (Pb). Kurşun, kimyasal gübreler ve herbisidler içinde yer almaktadır. Ayrıca, besinlerde doğal veya katkı maddesi olarak bulunabilmektedir. Kurşun, plasentadan kolaylıkla geçmekte ve bu nedenle çocukların $\mathrm{Pb}$ ile teması prenatal dönemde başlamaktadır. Enzim inhibitörü olarak kurşun, yaşamın erken dönemlerinden itibaren sağlı sorunlarına neden olabilmektedir. Özellikle meyveler, sebzeler, et, tahıllar, deniz ürünleri, su ve meșrubatlar $\mathrm{Pb}$ içermekle birlikte besinlerin konserve yoluyla saklanması kurşun içeriğini önemli düzeyde arttırmaktadır. ${ }^{16}$ Bununla birlikte besinlerdeki $\mathrm{Pb}$ içeriğine yönelik yapılan bir çalışmada, en yüksek $\mathrm{Pb}$ düzeylerine sahip 
yiyecekler arasında çikolatalı şekerlemeler (48.7 $\mu \mathrm{g} / \mathrm{kg})$, yeşil yapraklı sebzeler (39.0 $\mu \mathrm{g} / \mathrm{kg})$ ile diğer sebzeler $(42.2 \mu \mathrm{g} / \mathrm{kg})$ ve kabuklular ile yumuşakçalar $(39.0 \mu \mathrm{g} / \mathrm{kg})$ bulunduğu belirtilmiștir. ${ }^{17}$ Çocuk ve adolesanların günlük beslenmesinde tüketim sıklığı ve miktarı giderek artan şeker ve şekerli ürünlere, çeşitliliği artırmak amacıyla farklı bileşenlerin eklenmesi de ağır metal kontaminasyonu riskini artırmaktadır. Farklı çikolata ve şekerlemelerden oluşan 69 ürünün incelendiği bir çalışmada, kakao bazlı ürünlerin ağır metal içeriklerinin süt ve şeker bazlı ürünlere kıyasla daha yüksek olduğu saptanmıștır. Ayrıca çocukların şekerli yiyeceklerden aldıkları ağır metaller değerlendirildiğinde sırasıyla en yüksek $\mathrm{Pb}$, $\mathrm{Zn}, \mathrm{Ni}, \mathrm{Cd}$ ve $\mathrm{Cu}$ aldıkları belirlenmiştir. Araştırma sonunda, çocukların şeker ve çikolata tüketimi yoluyla ağır metal kontaminasyonuna karşı savunmasız oldukları, maruziyeti azaltmak için bu ürünlerin içeriklerinin özellikle $\mathrm{Pb}$ açısından düzenli olarak izlenmesi gerektiği ifade edilmiştir. ${ }^{16}$ Rusya'da yapılan bir çalışmada, 489 erkek çocuk incelenmiş ve serum değerlerinde yüksek $\mathrm{Pb}$ düzeyleri belirlenmiştir. Ayrıca serum $\mathrm{Pb}$ düzeyleri gecikmiş puberte ile ilişkilendirilmiştir.18 Koreli kız çocukları ile yürütülen bir diğer çalışmada ise serum $\mathrm{Pb}$ düzeyleri ile erken pubertal gelişim arasında anlamlı düzeyde pozitif bir ilişki saptanmıştır. ${ }^{19}$

\section{b. Kadmiyum}

Kadmiyum (Cd), maden ocağı ve endüstriyel artıklarda yüksek miktarda bulunabilmektedir. Ayrıca, Cd içeren fosforlu gübrelerin kullanılması yeraltı su kaynaklarının, toprağın ve göllerin $\mathrm{Cd}$ ile kontamine olmasina ve toprak mahsullerinin, farklı hayvan türlerinin ve deniz canlılarının olumsuz yönde etkilenmesine neden olmaktadır. Özellikle $\mathrm{Cd}$ ile kontamine toprakta yetişen yeșil yapraklı sebzeler, patates, havuç, kereviz gibi yumru sebzeler, mısır, pirinç, buğday gibi tahıllar ve yağlı tohumlarda $\mathrm{Cd}$ yüksek konsantrasyonda bulunmaktadır. Ayrıca kabuklu deniz hayvanlarında (istiridye, yengeç), yumuşakçalarda, hayvan sakatatlarında (özellikle yaşlı hayvanların karaciğer ve böbreklerinde), yabani mantarlarda Cd düzeyi yüksektir. ${ }^{20}$ Çin'de endüstriyel fabrikalardan açığa çıkan Cd'un pirinç tarlalarındaki ağır metal kirliliğinin en önemli nedeni olduğu öne sürülmektedir..21 Yapılan bir çalışmada, geç menarş yaşı saptanan kız çocuklarında Cd seviyelerinin yüksek düzeyde olduğu belirlenmiștir. ${ }^{22} \mathrm{Bir}$ diğer çalışmada, 12-14 yaşlarında 111 erkek çocuğu değerlendirilmiş ve yüksek Cd düzeyi ile gecikmiş puberte, daha küçük testis hacmi ve daha düşük testosteron düzeyi arasında ilişki saptanmıştır. ${ }^{23}$

c. Civa

Civa (Hg), tarımda tohumların korunması için fungusit nitelikli ilaçların içerisinde yer almaktadır. Ayrıca Hg temasında, Hg ile kirlenmiş sularda yaşayan büyük balıklar en önemli kaynaktır. Buna ek olarak; obezite, insülin direnci, yağlı karaciğer hastalığı gibi birçok hastalığın gelişme riskini artıran yüksek fruktozlu misır şurubunun da $\mathrm{Hg}$ açısından iyi bir kaynak olduğu belirtilmektedir. ${ }^{24}$ Yapılan bir çalışmada, erken puberte görülen Kore'li kız çocuklarının serum $\mathrm{Pb}$ ve $\mathrm{Hg}$ düzeylerinin yüksek olduğu saptanmıștır. ${ }^{25}$

Amerika'da yürütülen 1512 anne ve çocuğunun incelendiği bir kohort çalışmasında ise prenatal dönemde yüksek düzeyde Hg'ye maruz kalan annelerin çocukları sonraki yıllarda incelendiğinde bu çocuklarda erken pubertal gelişimin olduğu gözlemlenmiştir. ${ }^{26}$

\section{d. Arsenik}

Arsenik (As), hayvansal tarım ve ilaç sanayisi gibi birçok endüstri bölgesinde su kaynaklarına ve çevreye kolayca geçiş yapmaktadır. $\mathrm{Bu}$ nedenle deniz ürünleri As açısından zengin kaynaklar haline gelebilmektedir. Buna ek olarak, pirinçte, pirinç ürünleri ile oluşturulan bebek formülalarında ve besinlerinde oldukça yüksek oranda As olduğu belirlenmiştir. ${ }^{27}$ Bazı gübreler ve tarımsal faaliyetlerde kullanılan kimyasal maddeler, yüksek düzeyde ağır metaller içermekte ve bu durum da besinlerde endokrin bozucuların konsantrasyonunu artırabilmektedir. Örneğin, yapılan bir çalışmada, durum buğdayı üretiminde kullanılan pestisitlerin; 
$\mathrm{Pb}, \quad \mathrm{Cd}$ ve As kirliliğine neden olduğu saptanmıştır. ${ }^{28}$ Özellikle As maruziyeti ile mRNA ekspresyonlarının ve hipotalamusta GnRH düzeylerinin arttığl ve bu durumun erken puberte ile ilişkili olduğu öne sürülmüştür. ${ }^{29}$

\section{e. Bakır}

Bakır ( $\mathrm{Cu})$, sanayinin tüm alanlarında kullanılmakla birlikte tarım ilaçlarında da bulunmaktadır. Besinlerin hazırlanmasında ve pişirilmesinde kullanılan mutfak araç gereçlerinden, besinlere önemli miktarda $\mathrm{Cu}$ geçişi olabilmektedir. Bu nedenle, daha çok paslanmaz çelikten üretilen pişirme ve saklama araçlarının kullanılması önerilmektedir. ${ }^{30}$ Türkiye'de yapılan bir çalışmada, 64 çeşit durum buğdayı analiz edilmiş ve tüm örneklerde $\mathrm{Al}, \mathrm{Cu}, \mathrm{Fe}, \mathrm{Mn}$ ve Zn miktarının yüksek düzeylerde olduğu saptanmıştır. ${ }^{31}$ Yapılan başka bir çalışmada, 47 adölesan dahil edilmiş ve serum $\mathrm{Cu}$ düzeyi ile pubertal gelişim arasında bir ilişki belirlenmemiștir. ${ }^{32}$

\section{f. Flor}

İçme suları da ağır metal açısından diğer bir risk kaynağıdır. Özellikle endüstriyel atıklar, içme sularına karışabilmektedirler. İçme sularındaki ağır metallere ek olarak, flor içeriklerinin de puberte zamanını etkilediği öne sürülmektedir. Yapılan bir çalışmada, 10-17 yaşlarında 157 erkek ve 176 kız çocuğunun idrar örnekleri değerlendirildiğinde, erkek çocuklarında üriner flor ile geç pubik kıllanması ve geç genital gelişim arasında anlamlı düzeyde bir ilişki saptanmıştır. ${ }^{33}$

\section{Bisfenol A}

Bisfenol A (BPA), plastik kaplama malzemesi olarak kullanılmakta ve özellikle bebek formülaları ve içeceklerinin şişelerinde yer almaktadır. Düşük konsantrasyonda iken zayıf düzeyde östrojenik etki gösterirken, yüksek konsantrasyonda olduğunda endojen östrojenle yarışmakta ve anti-androjenik etki göstermektedir. Bisfenol A'nın puberte üzerine etkilerini değerlendiren bir çalışmada, erken pubertal gelişim gösteren kız çocuklarının idrarlarında kontrol grubuna kıyasla daha yüksek BPA düzeyine rastlanmıştır. ${ }^{34}$ Türkiye'de yapılan bir çalışmada ise 42 idiyopatik erken puberteli, 42 periferal erken puberteli ve 50 ayn yaştaki sağlıklı obez olmayan kız çocuğu kıyaslandığında gruplar arasında üriner BPA, LH, FSH veya östradiol düzeyleri açısından anlamlı bir farklılık bulunmamıştır. ${ }^{35}$ Wang ve ark.'nın 671 Çinli erkek çocuğunu dahil ettikleri bir çalışmada, orta düzeyde yüksek üriner BPA konsantrasyonuna sahip olan çocuklarda pubik kıllanma ve testikular büyüme gözlenmiştir. ${ }^{36}$ BPA maruziyetinin erken yaşlarda genital olgunlaşmaya neden olduğu ve beden kütle indeksi düzeylerinin bu durumu değiștirmediğini ifade etmişlerdir.

\section{Fitalatlar}

Fitalatlar, plastiklere esneklik verilmesi amacıyla kullanılmaktadır. Oyuncaklar, yapı malzemeleri, yüksek moleküler ağırlıklı bileşikler ve çözücüler, kozmetikler gibi birçok bileşende yer almaktadır. Oral ve solunum yol başta olmak üzere birçok yolla maruziyet görülebilmektedir. ${ }^{37}$ Kore'de yapılan bir çalışmada, yüksek serum fitalat düzeylerine sahip olan kız çocuklarının, düşük fitalat maruziyeti olanlara kıyasla erken pubertal gelişim gösterdikleri belirlenmiştir. ${ }^{38}$

\section{Dioksinler}

Dioksinler endüstriyel faaliyetler sonucunda, klor varlı̆̆ında organik bileșenlerin yüksek sıcaklıklara maruz kalmasıyla oluşan bileşiklerdir. Dioksinler toksik olup önemli derecede karsinojenik etkilere sahiptirler. Özellikle 2,3,7,8-TCDD olarak bilinen dioksin bileşiğinin toksik etkisinin aflatoksinlerden 600 kat daha fazla olduğu belirtilmektedir. Su, hava ve toprak gibi ortamlara kontamine olup, bu ortamlar aracılığıyla özellikle canlıların yağ dokularında birikmektedir. Besinler içerisinde dioksinler açısından en riskli taşıyıcılar, su ürünleri, süt ve ürünleri, et ve ürünleri sayllabilmektedir. Ancak tüm bunlardan önce özellikle yem ve yem katkı maddeleri, dioksin kontaminasyonu açısından oldukça önemlidir. ${ }^{39}$ Dioksinler ve pubertal zaman arasındaki mekanizma henüz net olarak belirlenemese de, dioksinlerin östrojenik veya antiöstrojenik 
etkileri ile pubertal zaman üzerinde etkili olabileceği bildirilmektedir. ${ }^{40}$ Rusya'da yapılan bir kohort çalışmasında 8-9 yaşlarında 473 erkek çocuğu incelenmiş olup büyüme düzeyleri ve vücut kompozisyonları değerlendirilmiştir. Çalışma sonucunda çocukluk döneminde dioksin maruziyetinin vücut kompozisyonunda değişimler oluşturarak ve somatik büyümeyi tetikleyerek erken puberteye neden olduğu belirtilmiştir. ${ }^{41}$ Belçika'da erkek çocukları ile yapılan bir diğer çalışmada da benzer şekilde dioksinlere maruz kalanlarda kontrol grubuna kıyasla daha geç dönemde genital gelişim ve pubik kıllanma gözlenmiştir. Aynı çalışmada, çocukların annelerinin gebelik süresince maternal endokrin bozuculara maruz kalma düzeyi ile çocukların testis hacmi arasında negatif bir ilişki saptanmıștır. Sertoli hücre sayısına göre belirlenen testis hacmi göz önüne alındığında maruziyet sonucunda bu hücrelerde proliferasyonun engellendiği belirlenmiștir. ${ }^{42}$

\section{Pestisitler}

Besinler yoluyla maruz kalınan bir diğer endokrin bozucu ise pestisitlerdir. Pestisitler, hipotalamik-pitüiteradrenal ekseninde normal fonksiyonların engellenmesi yoluyla puberte zamanının değişimine neden olmaktadırlar. Michigan beslenme kohortu çalışmasına göre 1973 yılında meydana gelen bir endüstriyel kazada, bir yangın önleyici kimyasalı, bir besin takviyesi kimyasalı (yem sinıfı magnezyum oksit) yerine çiftlik hayvanı yemine yanlışlıkla eklenmiştir. Sonraki aylarda, Michigan'da yaşayan pek çok kişi farkında olmadan polikromlu bifenillerle (PBB) kontamine olmuş hayvan ve süt ürünlerini tüketmiştir. Bununla birlikte PBB kontaminasyonuna maruz kalan 4000 kadın prenatal ve laktasyon döneminde incelenmiștir. Kontaminasyondan 24 yll sonra 1997'de PBB düzeyi yüksek olan annelerin emzirilen kızlarında (11.6 yaş) emzirilmeyen kızlara (12.5 yaş) kıyasla erken menarş yaşı ve erken dönemde pubik kıllanma belirlenmiştir. Michigan kazasında erken menarş yaşı görülme durumu, PBB153 bileșeninin östrojenik etki göstermesi ile ilişki olabileceği öne sürülmüştür. ${ }^{43}$ Amerika'da yirminci yüzyılın başlarında
Büyük Göl endüstriyel atıklar nedeniyle temel olarak PCB ve diklorodifeniltrikloroetan (DDT) bileşenleri ile kirlenmeye başlamıştır. Bu bileșenler deniz ürünleri ile besin zinciri aracılığıyla insanlara ulaşmış olup sağlık açısından olumsuz etkilere neden olabileceği hipotezi öne sürülmüştür. Buna bağlı olarak, 2004 yılında $151 \mathrm{klz}$ çocuğunun incelendiği bir kohortta gebelik döneminde maternal PCB ve dikloro difenil dikloroetilen (DDE) konsantrasyonları değerlendirilmiş ve çalışmaya dahil edilen annelerin kız çocukları puberte döneminde incelenmiştir. Kız çocuklarının menarş yaşının 9-17 yaş aralığında değiştiği, PCB ile menarş yaşı arasında bir ilişki olmadığı ancak gebelik döneminde DDE maruziyetindeki 15 ug/L artışın menarş yaşını 1 yıl azalttığ saptanmıştır. dikloro difenil dikloroetilenin muhtemel mekanizmasının ise androjen blokerları içermesi, östrojen taklit edici etkileri veya C19 steroidlerinin östrojenlere dönüşümünü katalize eden bir enzim olan aromataz enziminin indüksiyonu yoluyla olduğu düşünülmüştür. ${ }^{44}$ Yaklaşık 2000 Tayvanlı birey 1978-1979 yılları arasında pirinç yağına kontamine olan PCB ve onların ısı ile bozulması sonucunda oluşan PCDF'lere maruz kalmıştır. Kontaminasyona maruz kalan 11-14 yaşlarında 55 erkek ve 55 maruziyete uğramamış erkek çocuk değerlendirildiğinde, kontrol grubuna kıyasla PCDF'lere maruz kalan çocuklarda penis boyunun daha kısa olduğu saptanmıştır. Bu etki PCB/PCDF'lerin aril hidrokarbon reseptörüne bağlanarak, sentez sırasında hücre içi biyoaktivasyonda veya hormonların bozulmasında rol oynayan enzimleri indükleyerek endokrin veya hücresel fonksiyonu bozarak gerçekleşmektedir. ${ }^{45}$

Kuzey Hindistan'da yaplan bir çalışmada, 20 yıldan fazla zamandır kaju fıstığı tarlalarında yılda iki veya üç kez havadan püskürtme yoluyla pestisid olarak kullanılan endosulfana maruz kalan yerli halk değerlendirilmiştir. Buna göre 10-19 yaşlarında olan yerli erkek çocukta ortalama endosulfan düzeyinin, kontrol grubuna kıyasla daha yüksek olduğu saptanmıştır. Ayrıca testosteron düzeyleri, cinsel olgunluk 
belirteci olan pubik kıllanma, penis ve testis boyutları belirgin düzeyde ve negatif yönde endosulfan maruziyeti ile ilişkili bulunmuştur. $\mathrm{Bu}$ sonuçlara göre özellikle prenatal veya prepubertal dönemde endosulfan maruziyetinin steroidogenezis ve spermatogenezis üzerinde engelleyici etki gösterdiği saptanmıştır. ${ }^{46}$

Bir başka tartışılan konu organik besin ve konvansiyonel besin kavramıdır. Yapılan bir çalışmada, evlerde ve tarımda kullanılan böcek ilacı 3-phenoxybenzoic acid (3-PBA) incelenmiş ve bu bileșenin kız çocuklarında meme gelişimi, pubik kıllanma ve erken menarşa, erkek çocuklarda ise erken yaşta testis hacminde artışa neden olduğu saptanmıștır. Ayrıca organik besinlerin tüketim sıklığı ile idrarda 3-PBA düzeyi arasında ters ilişki saptanmıștır. ${ }^{11}$

\section{Anabolik Hormonlar}

Anabolik hormonlar östradiol, testesteron, progesteron olup bu hormonları içeren hayvansal ürünlerin tüketilmesi ile çocukların üreme sistemlerinde belirgin olarak bozukluklar meydana gelebilmektedir. Östrojen içeren hayvansal kaynaklı besinlerin tüketilmesi ile özellikle erken puberte gözlenirken, androjenler ile seksüel farklılaşma ve beyin gelişiminde hasar görülebilmektedir. Amerika Gıda ve İlaç Dairesi (FDA) tarafından süt ve ürünlerinde \%1'den az olması şartıyla ekzojen hormonların etkisinin olmadığını belirtilse de bu konu ile ilgili henüz fikir birliği sağlanamamıştır. ${ }^{47}$

Süt ve süt ürünlerinde anabolik hormon düzeyinin, et ve ürünlerine klyasla daha yüksek olduğu belirtilmektedir. Diğer taraftan, işlenmiş hayvan ürünlerinin tüketilmesi ile alınan östradiol miktarı (500 g et başına 0.0045-0.180 $\mu \mathrm{g}$ ), insanın günlük hormon üretim miktarından yaklaşık kırk ila binlerce kat daha düşüktür. ${ }^{48}$

Hormon tedavisi uygulanmıș hayvanların et, süt ve ürünlerinin tüketimi yoluyla prepubertal erkeklerin $<14 \mu \mathrm{g} /$ gün, prepubertal kızların 10-24 $\mu \mathrm{g} /$ gün östrojen, prepubertal çocukların 150-250 $\mu \mathrm{g}$ /gün progesteron ve 30-100 $\mu \mathrm{g} /$ gün testosteron aldıkları ifade edilmektedir. ${ }^{48}$ Türkiye'de 30 taze et ve 30 et ürününde zeranol, trenbolon, dietilstilbestrol ve clenbuterol anabolik hormonları düzeyleri analiz edildiğinde, tüm örneklerde zeranol, 48 örnekte trenbolon, 21 örnekte ise dietilstilbestrol saptanırken hiçbir örnekte clenbuterol saptanmamıştır. Araştırmacılar, Türkiye'de et üretiminin sıkı bir şekilde denetlenmesi gerektiğini ifade etmişlerdir. ${ }^{49}$

Gida Katkıları FAO/WHO Ortak Uzmanlar Komitesi, 11ß-östradiolün NOAEL (hiçbir yan etki göstermeyen doz) düzeyinin $5 \mu \mathrm{g} / \mathrm{kg} /$ gün, ADI (günlük alınmasına izin verilen miktar) değerinin ise 0-0.5 $\mu \mathrm{g} / \mathrm{kg} /$ gün olduğunu belirtmiştir. Testeron için NOAEL ve ADI değerleri sırasıyla 1.700 $\mu \mathrm{g} / \mathrm{kg} /$ gün ve $0-2 \mu \mathrm{g} / \mathrm{kg} /$ gün; progesteron için $3.300 \mu \mathrm{g} / \mathrm{kg} /$ gün (en düşük yan etki gösteren doz/LOAEL) ve 0-30 $\mu \mathrm{g} / \mathrm{kg} /$ gün'dür. Östrojenik etkisi olan zeranol için NOAEL ve ADI değeri sırasıyla 50 $\mu \mathrm{g} / \mathrm{kg} /$ gün ve $0-0.5 \mu \mathrm{g} / \mathrm{kg} /$ gün; menstrüel döngüyü değiştirebilen melengesterol asetatın $5 \mu \mathrm{g} / \mathrm{kg} /$ gün ve $0-0.03 \mu \mathrm{g} / \mathrm{kg} /$ gün; androjenik etkisi olan trenbolon asetatın ise $2 \mu \mathrm{g} / \mathrm{kg} /$ gün ve 0-0.2 $\mu \mathrm{g} / \mathrm{kg} /$ gün'dür. ${ }^{48}$

\section{Sonuç}

Epidemiyolojik kanıtlar çelişkili ve yetersiz olmakla birlikte pubertal olgunlaşma ile endokrin bozucular arasında olası bir ilişki olduğu düşünülmektedir. Günümüzde endokrin bozucu bileșenlerden tamamen korunmak neredeyse olanaksızdır. $\mathrm{Bu}$ nedenle endokrin bozucuların sağlık üzerindeki etkilerini en aza indirmek için yaşam tarzı değişiklikleri, yeterli ve dengeli beslenme alışkanlıklarının geliştirilmesi, antioksidan özellik gösteren besin bileşenlerinin diyetle yeterli miktarda alınması özellikle endokrin bozucuların oluşturduğu oksidatif strese karşı koruyucu olabilmektedir. Diğer yandan, düzenli fiziksel aktivite yapılması da oksidatif, çevresel ve metabolik stresi azaltabilmektedir. Besinlerin hazırlanmasında hijyen ve sanitasyon kurallarına dikkat edilmesi besinler yolu ile endokrin bozuculara maruz kalınmasına karşı koruyucu olabilmektedir. Bunun için meyve ve sebzeler kullanılan tarım ilaçlarından arındırmak için iyi bir şekilde 
yıkanarak tüketilmelidir. Özellikle sanayi bölgeleri olmak üzere kontaminasyonun yüksek olduğu bölgelerden elde edilen balıklar ve bu balıklarla beslenen yaban hayvanlarının etlerinin tüketiminden mümkün olduğunca kaçınılmalıdır. Besin hazırlama ve saklamada kullanılan kapların besin ile etkileşime girmeyen bir malzemeden yapılmış olmasına (cam gibi) dikkat edilmelidir. Paketlenmiş ve çok işlem görmüş hazır besinlerin tüketim sıklığı ve miktarı mümkün olduğunca azaltılmalıdır.

Türkiyede üretilen besinlerde hangi pestisitin ne miktarda kullanılacağı, uluslararası düzeyde kabul görmüş ilkeler çerçevesinde Türk Gıda Kodeksi (TGK) “Gıda Maddelerinde Bulunmasına İzin Verilen Pestisitlerin Maksimum Kalıntı Limitleri Tebliği"ne göre belirlenmektedir. Yürürlükteki yasaya göre piyasaya arz edilecek besinlerdeki pestisit kalıntılarının bu tebliğde belirtilen sınır değerlerine uygun olması gerektiği bildirilmektedir.50 Gida maddelerinin Maksimum Kalıntı Limiti (MRL) değerlerinin üzerinde pestisit kalıntısı içermesi durumunda, tespit edilen pestisitin kalıntı miktarına, kimyasal ve toksik özelliğine ve gıda maddesinin tüketim miktarına bağlı olarak insan sağlığında akut ve kronik olmak üzere bazı olumsuz etkiler görülebilmektedir. Ayrıca Türkiye'de BFA ile ilgili yapılan düzenlemeler temel alındığında Gıda Maddeleri ile Temasta Bulunan Plastik Madde ve Malzemeler Hakkındaki Tebliğ'de BFA'nın spesifik migrasyon limiti $0.6 \mathrm{mg} / \mathrm{kg}$ olarak belirtilmiştir.51 $\mathrm{Bu}$ bağlamda, besinlerdeki endokrin bozucu düzeyleri, kronik toksisite düzeyleri, alternatif ambalaj materyalleri ve sağlığa etkileri ile ilgili çalışmaların arttırılması yanında yasal düzenlemeler doğrultusunda bu endokrin bozucuların kontaminasyonunun kontrol altında tutulma gerekliliği de oldukça önem taşımaktadır. Sonuç olarak, besinler kullanılan tarım ilaçları, hazırlama, depolama ve taşıma, koşulları nedeniyle endokrin bozucular için taşıyıcı olabilmektedirler. Bu nedenle hem sağliklı bir yaşam sürdürebilmek hem de sürdürülebilir bir yaşamı gelecek nesiller için imkânlı hale getirebilmek amacıyla sağlıklı yaşam tarzı değişikliklerin hayata geçirilmesine önem verilmelidir.

Yazar katkıları: $\mathrm{Bu}$ makalede, her iki yazar da literatür taranması, analiz edilmesi ve derlemenin yazılması aşamalarında birlikte çalışmışlardır.

Çıkar çatışması: Yazarlar arasında herhangi bir çıkar çatışması bulunmamaktadır.

Mali destek: Bu çalışma sırasında kamu, ticari veya kar amacı gütmeyen sektörlerdeki fon ajanslarından herhangi bir destek alınmamıştır.

\section{Kaynaklar}

1. Bradley SH, Lawrence N, Steele C, Mohamed Z. Precocious puberty. Bmj 2020;368. doi: 10.1136/bmj.16597.

2. Şahin Ş, Özçelik ÇÇ. Ergenlik dönemi ve sosyalleșme. Cumhuriyet Hemşirelik Dergisi 2016;5(1):42-9.

3. Çatlı G, Erdem P, Anık A, Abacı A, Böber E. Santral erken puberte ve prematür telarş ayırıcı tanısında klinik ve laboratuvar bulgular. Turk Pediatri Ars 2015;50(1):20-6.

4. Köseoğlu SZA, Çelebi Tayfur A. Adölesan Dönemi Beslenme ve Sorunları. 2017.

5. Gonsioroski A, Mourikes VE, Flaws JA. Endocrine disruptors in water and their effects on the reproductive system. Int J Mol Sci 2020;21(6):1929.

6. Jefferson WN, Patisaul HB, Williams CJ. Reproductive consequences of developmental phytoestrogen exposure. Reprod 2012;143(3):247.

7. Adgent MA, Daniels JL, Rogan WJ, Adair L, Edwards LJ, Westreich D, et al. Early-life soy exposure and age at menarche. Paediatr Perinat Epidemiol 2012;26(2):163-75. 
8. Yum T, Lee S, Kim Y. Association between precocious puberty and some endocrine disruptors in human plasma. J Environ Sci Health C 2013;48(8):912-7.

9. Segovia-Siapco G, Pribis P, Oda K, Sabaté J. Soy isoflavone consumption and age at pubarche in adolescent males. Eur J Nutr 2018;57(6):2287-94.

10. Aksan A, Özdemir A. Endokrin Bozucular. Hacettepe University Faculty of Health Sciences J 2016;3(2).

11. Ye X, Pan W, Zhao Y, Zhao S, Zhu Y, Liu W, et al. Association of pyrethroids exposure with onset of puberty in Chinese girls. Environ Pollut 2017;227:606-12.

12. Wielogorska E, Elliott C, Danaher M, Connolly L. Endocrine disruptor activity of multiple environmental food chain contaminants. Toxicol In Vitro 2015;29(1):211-20.

13. Gálvez-Ontiveros $Y$, Páez S, Monteagudo C, Rivas A. Endocrine disruptors in food: impact on gut microbiota and metabolic diseases. Nutrients 2020;12(4):1158.

14. Lomniczi A, Wright $H$, Ojeda SR. Epigenetic regulation of female puberty. Front Endocrinol 2015;36:90-107.

15. Hamzaoglu O, Yavuz M, Turker G, Savli H. Air pollution and heavy metal concentration in colostrum and meconium in two different districts of an industrial city: a preliminary report. Int Med J 2014;21(1):77-82.

16. Devi P, Bajala V, Garg V, Mor S, Ravindra K. Heavy metal content in various types of candies and their daily dietary intake by children. Environ Monit Asses 2016;188(2):86.

17. Malavolti M, Fairweather-Tait SJ, Malagoli C, Vescovi L, Vinceti M, Filippini T. Lead exposure in an Italian population: Food content, dietary intake and risk assessment. Food Res Int 2020;137:109370.

18. Williams PL, Sergeyev O, Lee MM, Korrick SA, Burns JS, Humblet O, et al. Blood lead levels and delayed onset of puberty in a longitudinal study of Russian boys. Pediatrics 2010;125(5):e1088-e96.

19. Choi HS. Relationships of Lead, Mercury and Cadmium Levels with the Timing of Menarche among Korean Girls. Child Health Nurs Res 2020;26(1):98-106.

20. Bakar C, Baba A. Metaller ve İnsan Sağliği: Yirminci Yüzyildan Bugüne ve Geleceğe Miras Kalan Çevre Sağliği Sorunu. 2009.

21. Zhang BQ, Liu XS, Feng SJ, Zhao YN, Wang LL, Rono JK, Li H, Yang ZM. Developing a cadmium resistant rice genotype with OsHIPP29 locus for limiting cadmium accumulation in the paddy crop. Chemosphere 2020;247:125958.

22. Rull RP, Canchola AJ, Reynolds P, HornRoss PL. Urinary cadmium and the timing of menarche and pubertal development in girls. J Adolesc Health 2014;54(2):1-10.

23. Interdonato M, Pizzino G, Bitto A, Galfo F, Irrera $\mathrm{N}$, Mecchio $\mathrm{A}$, et al. Cadmium delays puberty onset and testis growth in adolescents. Clin Endocrinol 2015;83(3):357-62.

24. Ravichandran S. Possible natural ways to eliminate toxic heavy metals. International Journal of Chemtech Research CODEN (USA), IJCRCC. 2011;3(4):1886-90.

25. Choi HS, Choi HS. Relationships of Lead, Mercury and Cadmium Levels with the Timing of Menarche among Korean Girls. Child Health Nurs Res 2020;26(1):98-106.

26. Wang G, Tang WY, Ji H, Wang X. Prenatal exposure to mercury and precocious puberty: a prospective birth cohort study. Hum Reprod 2021;36(3):712-20.

27. Munera-Picazo S, Cano-Lamadrid $M$, Castaño-Iglesias MC, Burló F, CarbonellBarrachina ÁA. Arsenic in your food: potential health hazards from arsenic found in rice. Nutr Diet Suppl 2015;7:1-10.

28. Atafar Z, Mesdaghinia A, Nouri J, Homaee M, Yunesian M, Ahmadimoghaddam M, et al. Effect of fertilizer application on soil heavy metal concentration. Environ Monit Assess 2010;160(1-4):83. 
29. Li X, Sun Z, Manthari RK, Li M, Guo Q, Wang J. Effect of gestational exposure to arsenic on puberty in offspring female mice. Chemosphere 2018;202:119-26.

30. Özbolat G, Tuli A. Ağır metal toksisitesinin insan sağlığına etkileri. Arșiv Kaynak Tarama Derg 2016;25(4):502-21.

31. Harmankaya M, Özcan MM, Gezgin S. Variation of heavy metal and micro and macro element concentrations of bread and durum wheats and their relationship in grain of Turkish wheat cultivars. Environ Monit Assess 2012;184(9):551121.

32. Urbano MR, Vitalle MS, Juliano Y, Amancio OM. Iron, copper and zinc in adolescents during pubertal growth spurt. J Pediatr (Rio J) 2002;78(4):327-34.

33. Liu Y, Tellez-Rojo M, Hu H, Sanchez BN, Martinez-Mier EA, Basu N, et al. Fluoride exposure and pubertal development in children living in Mexico City. Environ Health 2019;18(1):26.

34. Supornsilchai V, Jantarat C, Nosoognoen W, Pornkunwilai S, Wacharasindhu S, Soder O. Increased levels of bisphenol A (BPA) in Thai girls with precocious puberty. J Pediatr Endocrinol Metab 2016;29(11):1233-9.

35. Bulus AD, Asci A, Erkekoglu P, Balci A, Andiran N, Kocer-Gumusel B. The evaluation of possible role of endocrine disruptors in central and peripheral precocious puberty. Toxicol Mech Methods 2016;26(7):493-500.

36. Wang Z, Li D, Miao M, Liang H, Chen J, Zhou Z, et al. Urine bisphenol A and pubertal development in boys. Int J Hyg Environ Health 2017;220(1):43-50.

37. Yang C, Harris SA, Jantunen LM, Kvasnicka J, Nguyen LV, Diamond ML. Phthalates: relationships between air, dust, electronic devices, and hands with implications for exposure. Environ Sci Technol 2020;54(13):8186-97.

38. Park O, Park JT, Chi Y, Kwak K. Association of phthalates and early menarche in Korean adolescent girls from
Korean National Environmental Health Survey (KoNEHS) 2015-2017. Ann Occup Environ Med 2021;33.

39. World Health Organization. Preventing disease through healthy environments: exposure to highly hazardous pesticides: a major public health concern. 2019.

40. Lucaccioni L, Trevisani V, Marrozzini L, Bertoncelli N, Predieri B, Lugli L, Berardi $A$, Iughetti L. Endocrine-disrupting chemicals and their effects during female puberty: a review of current evidence. Int J Mol Sci 2020;21(6):2078.

41. Burns JS, Williams PL, Sergeyev O, Korrick SA, Rudnev S, Plaku-Alakbarova B, Revich B, Hauser R, Lee MM. Associations of peri-pubertal serum dioxins and polychlorinated biphenyls with growth and body composition among Russian boys in a longitudinal cohort. Int $J$ Hyg Environ Health 2020;223(1):228-37.

42. Schoeters G, Den Hond E, Dhooge W, van Larebeke N, Leijs M. Endocrine disruptors and abnormalities of pubertal development. Basic Clin Pharmacol Toxicol 2008;102(2):168-75.

43. Blanck HM, Marcus M, Tolbert PE, Rubin C, Henderson AK, Hertzberg VS, et al. Age at menarche and tanner stage in girls exposed in utero and postnatally to polybrominated biphenyl. Epidemiology 2000;11(6):641-7.

44. Vasiliu 0, Muttineni J, Karmaus W. In utero exposure to organochlorines and age at menarche. Hum Reprod 2004;19(7):1506-12.

45. Guo YL, Lambert GH, Hsu CC, Hsu MM. Yucheng: health effects of prenatal exposure to polychlorinated biphenyls and dibenzofurans. Int Arch Occup Environ Health 2004;77(3):153-8.

46. Saiyed H, Dewan A, Bhatnagar V, Shenoy $\mathrm{U}$, Shenoy R, Rajmohan $\mathrm{H}$, et al. Effect of endosulfan on male reproductive development. Environ Health Perspect 2003;111(16):1958-62.

47. Snoj T. Hormones in Food as a Potential Risk for Human Reproductive and Health 
Disorders. Acta Veterinaria 2019;69(2):137-52.

48. Jeong SH, Kang D, Lim MW, Kang CS, Sung HJ. Risk assessment of growth hormones and antimicrobial residues in meat. Toxicol Res 2010;26(4):301-13.

49. BN H, Aydın A, Hampikyan H. The presence of some anabolic residues in meat and meat products sold in Istanbul. TurkJ Vet Anim Sci 2005;29(29):691-9.
50. TGK. Türk Gıda Kodeksi. Türk Gida Kodeksi Pestisitlerin Maksimum Kalinti Limitleri Yönetmeliği. 2016. https://www.resmigazete.gov.tr/eskiler /2016/11/20161125M1-1.htm. 1 Mart 2021 tarihinde erişilmiștir.

51. TGK. Türk Gıda Kodeksi. Türk Gida Kodeksi Pestisitlerin Maksimum Kalinti Limitleri Yönetmeliği. 2013. https://www.resmigazete.gov.tr/eskiler /2013/07/20130717-5.htm. 1 Mart 2021 tarihinde erişilmiştir. 